Original Research Paper

\title{
The Quaternary Mammals from Kozhamzhar Locality (Pavlodar Region, Kazakhstan)
}

\author{
${ }^{1}$ Andrei Valerievich Shpansky, \\ ${ }^{2}$ Valentina Nurmagambetovna Aliyassova and ${ }^{1}$ Svetlana Anatolievna Ilyina \\ ${ }^{I}$ Tomsk State University, Tomsk, Russia \\ ${ }^{2}$ Pavlodar State Pedagogical Institute, Pavlodar, Kazakhstan
}

\author{
Article history \\ Received: 26-11-2015 \\ Revised: 06-02-2016 \\ Accepted: 10-02-2016 \\ Corresponding Author: \\ Valentina Nurmagambetovna \\ Aliyassova, \\ Pavlodar State Pedagogical \\ Institute, Pavlodar, Kazakhstan \\ Email: alijasova@mail.ru
}

\begin{abstract}
A new locality of fossil mammals near Kozhamzhar in Pavlodar Priirtysh Region has been described. The article provides the description of the quaternary sediments section found in the outcrop near Kozhamzhar. In the Karginian Age (MIS 3) alluvial deposits of the described locality we found the remains of Elasmotherium sibiricum, Mammuthus ex gr. trogontherii-chosaricus, Mammuthus primigenius, Bison sp. AMS Radiocarbon dating of the Elasmotherium skull gave a young age$26038 \pm 356$ BP (UBA-30522). The skull of Elasmotherium sibiricum exceeds in size the skull of the mammals from Eastern Europe. The lower jaw of the elephant, considering the size and the morphology of the last dentition teeth, is very close to that of Mammuthus trogontherii chosaricus.
\end{abstract}

Keywords: Pavlodar Region, Middle and Late Pleistocene, Mammuthus ex gr. Trogontherii-chosaricus, Mammuthus primigenius, Elasmotherium sibiricum, Morphology, Biostratigraphy

\section{Introduction}

The remains of fossil mammals from Late Cenozoic are found very often but irregularly on the territory of Pavlodar region. Mostly, they are found on the sandbanks or in the outcroppings of river terraces. The age period of the known localities covers the time from late Miocene to Holocene. The most numerous are the localities of mammals from Middle and Late Pleistocene. In Pavlodar Priirtysh area the Pyateryzhskoye and Grigoryevka localities are confined to the Middle Pleistocene. Presumably, the remains of large-sized mammals discovered in sections near Yamyshevo settlement and the one in between Moiseyevka and Zhelezinka originate from the sediments of midpleistocene; the species composition and the position within the sections should be verified for those localities.

The remnant diggings of the Quaternary mammals in the Irtysh floodplain terrace sediments were performed extensively in the 1950-70 s by the staff of paleozoology laboratory from the Institute of Zoology (Almaty) and by several geologic organizations, which used to send the collected materials for identification to Geological Institute of Academy of Science of Russia (Moscow). Considerable and often unique materials are presented in Pavlodar Regional Museum of Local Lore, History and Economy (Pavlodar) (Shpansky, 2014). New materials are collected by the staff of Pavlodar State Pedagogical
Institute (PSPI), Pavlodar House of Geography (Pavlodar, Kazakhstan) and Tomsk State University (Tomsk, Russia). Presently, the collection of the PSPI Nature Museum is the most numerous one (among the museums of Pavlodar) and has in its possession the osteological materials from several localities, including the fragment of the skeleton belonging to Mammuthus trogontherii (Pohlig) from Pyateryzhsk settlement (Shpansky et al., 2008), as well as the important materials from Grigoryevka (Shpansky et al., 2007).

This article is dedicated to analyzing the new facts of discovering the remains of large-sized mammals in Kozhamzhar locality.

The following abbreviations have been used in the article: Geological Institute of Russian Academy of Sciences (GINRAS) (Moscow, Russia), Institute of Zoology (IZ) (Almaty, the Republic of Kazakhstan); Museum of Nature at Pavlodar State Pedagogical Institute (MN PSPI) (Pavlodar, the Republic of Kazakhstan); Paleontology Institute of Russian Academy of Sciences (PINRAS) (Russia, Moscow); Saratov Museum of Local Lore (SLLM), History and Economy (Saratov, Russia); Zoology Institute of Russian Academy of Sciences (ZINRAS) (Russia, Saint-Petersburg); Institute of Archaeology and Ethnography (IAE) of Siberian Branch, Russian Academy of Sciences (Russia, Novosibirsk); sign "C" before a numeric value in the tables means the incomplete measurement of the bone. 


\section{Geographical and Geological Position of the Kozhamzhar Locality}

The study of fossil mammals from paleontological locality near Kozhamzhar in Pavlodar Priirtysh and their species identification allow undertaking a comparison of the obtained set with already known localities of Pavlodar Priirtysh Region and evaluating the stratigraphic position of the studied taphocoenosis.

The Quaternary sediments section is situated on the left bank of the Irtysh River, $120 \mathrm{~km}$ to the North-West of Pavlodar, directly downstream from Aktogay settlement (till 1995 it was named Krasnokutsk) to Kozhamzhar in Aktogay District (Fig. 1). The section length is about $8 \mathrm{~km}$. While investigating the section in 2011 and 2015, it was noted that the bank of the Irtysh River was being extensively washed away downstream Aktogay and near Kozhamzhar village and the plinth terrace of the Irtysh River was becoming cropped out. The most outcropped parts of the section have the coordinates near Aktogay as follows: $53^{\circ} 01^{\prime} 02^{\prime \prime}$ north latitude, $75^{\circ} 57^{\prime} 40^{\prime \prime}$ east longitude, near Kozhamzhar: $53^{\circ} 01^{\prime} 59^{\prime \prime}$ north latitude, $75^{\circ} 52^{\prime} 18^{\prime \prime}$ east longitude. The middle part of the section, with the length about $4 \mathrm{~km}$ is not being washed out currently (it is represented by sodded taluses) and is distanced from the bed part of the Irtysh by up to $300-500 \mathrm{~m}$. The structure of the section in both outcrops is identical.

Local residents admit finding bone fragments in the downstream outcrop (near Kozhamzhar village), the most part of which have been lost. Earlier, this section was described by Zinova (1982) in the study named "Dawn" (after the name of a state farm which was located here), in the geologic sources the mammal locality was also known under the name of Krasnokutsk, based on the part of the bone materials collected here. Zhylkibayev (1975) notes the discovery of the lower left tooth of Khozar elephant, made by M.B. Kuyanets in 1964 near Zhdanovo settlement (now Leningradskoye village) $1 \mathrm{~km}$ downstream Aktogay. Kozamkulova (1969) notes finding several bones of bison in Krasnokutsk.

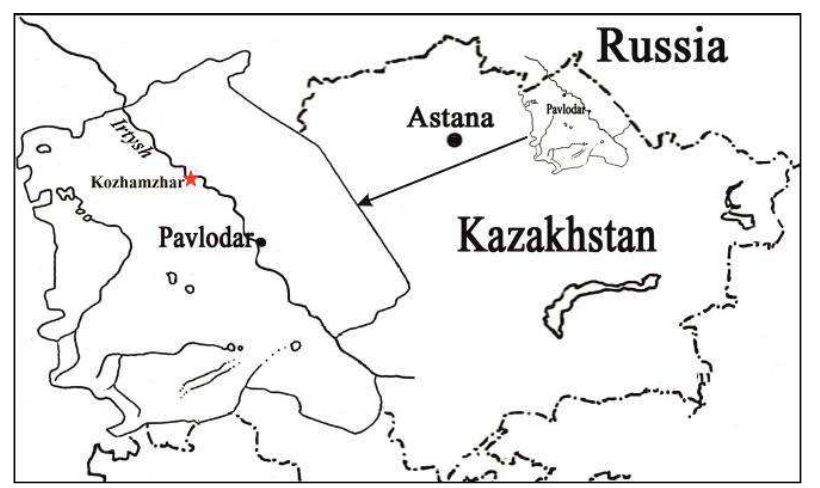

Fig. 1. Geographical situation of Kozhamzhar locality (Pavlodar region)
The remains of the mammals described below were delivered to the Museum of Nature at Pavlodar State Pedagogical Institute in autumn of 2010. In fact, the collecting was done by a local resident of Kozhamzhar K.S. Khayrulin in 1988-1989 in the "downstream" outcropping. The remains were deposited at the depth of 5 meters from the upper layer of the terrace, in the upper part the overlapping horizontal-oblique layered sands of layer 6 (Fig. 2). Below is given the description of the section of quaternary sediments in outcropping near Kozhamzhar, this part of the section has more steep outcropping and less taluses; the layers are cropped out from the top down as follows:

Lithologic section and the specific features Depth, $m$ of the layer occurrence

1 Soil layer, humus, dense, dark-brown 0.4

2 Loess loam, light-brown, dense, non-laminated, porous, with vertical cleavage (holds the wall well), lightly carbonized, in some places has thin inlayers of fine-grained sand. Lower boundary is sharp, even

3 Grey-brown sandy loams, in lower part changing into horizontally layered sands with diverse grain sizes from fine to mid-coarse grains and the coloring changes from light-brown to reddish-brown, iron bearing. Lower boundary is sharp, but not even

4 Grey coarse-grained sands with small pebble 0.1-0.6 inclusions (up to $5 \mathrm{~mm}$ ), with horizontal and oblique layering, irregular in spreading, blowing out and with bulges

5 Different size grain sands, light-brown with thin $1.0-1.5$ slightly inclined layering

6 Horizontal and oblique layered sands, fine grained with overlapping layers with coarsegrained sands and pebbles (up to $1.5-2 \mathrm{~cm}$ ). Oblique layered series have the depth up to 10$15 \mathrm{~cm}$. The coloring of the sands often changes from grey to reddish. The lower boundary is sharp and even. At the bordering of the layer the remains of large-sized mammals were found

7 Coarse-grained sands with small pebbles rich in 0.1-0.2 iron oxides and of rust-brown color. The lower boundary is sharp, even

8 Massive, dense, bluish, bluish-grey clays with clear thin horizontal ribbon-like layering, soft, cut easily with an instrument, viscous, in some places mixing with siltstones. Upper $8-10 \mathrm{~cm}$ of clays contacting with sands are saturated with $\mathrm{Fe}$ oxides, are of brown color, becoming brittle, crumble easily. When the clay gets dry it becomes light-grey, almost white and very hard. In the lower part of the layer at the plane of stratification there are thing layers of light-grey sand and the developments of thin packing of iron hydroxides. Pancake-shaped siderite inclusions occur. Those go down under water edge. 


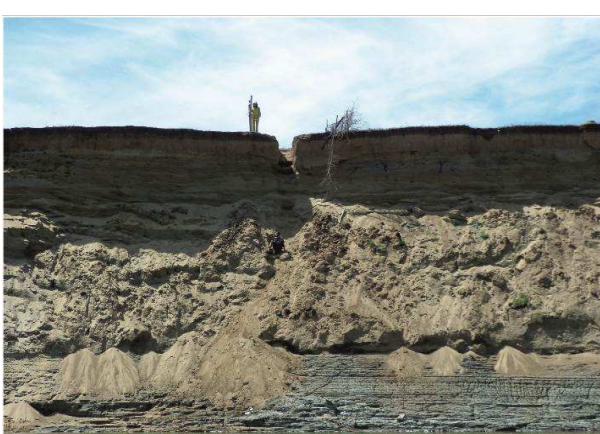

(a)
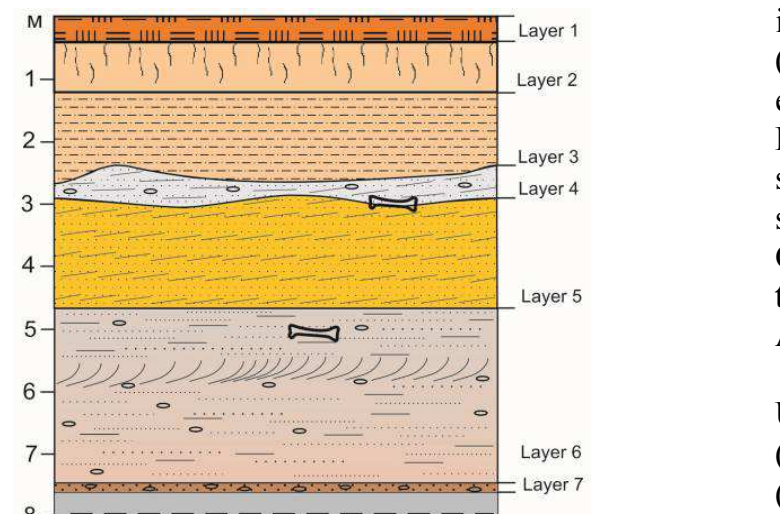

$8--\cdots----\cdots-$

$----------$

$9------------$

10- - - - - - - - -

- - - - - - - - - -

$1-$

--------
------1

$12-$

$---\div--------$

$13-$

14-

$------------$

$---------$

$15-$

$---------$

$16-$

$-------1$

---------1 Layer

Legend
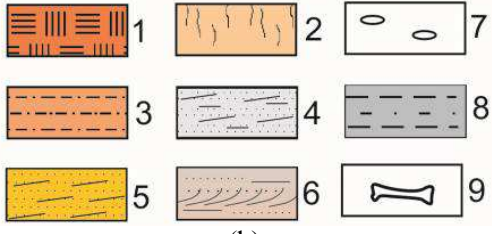

5

(b)

Fig. 2. (a) General view of the quaternary deposits of Irtysh River near Kozhamzhar (Pavlodar region), (b) Section plan of the quaternary deposits of Irtysh River near Kozhamzhar (Pavlodar region): 1-soilvegetable bed; 2-loess loam; 3-loams and loamy sands 4-sands with horizontal and slant bedding; 5oblique bedding sands; 6-anisomerous, interstratifying sands; 7-pebble; 8-blue-gray clays with siltstone inclusions; 9-remains of mammals
Overall height of the terrace from the water edge amounts to $16.5-17.3 \mathrm{~m}$ in the low-water season. The described outcropping has clearly expressed two-level structure: The lower part is made of layer 8, represented by lacustrine layered clay sediments, predominantly of dove and blue-grey color. According to Zinova (1973), the clays form sediments from Krasnokutsk (= Katchiry) suites of the very end of Upper Pliocene. The clays with erosion are overlapped by different-age Quaternary sediments, making up the third terrace above the flood plain. The section between Aktogay and Kozhamzhar is identified as a stratotype of the Krasnokutsk suite (Zinova, 1973). Svaritchevskaya and Ten (1966) estimate the age of Krasnokutsk suite as Middle Pliocene. According to Zinova (1982), the age of these sediments, based on malacofauna and sporo-pollen spectrum, is estimated now as Early Pleistocene (= Calabrian?) and is associated with the upper bed of the Kotchkovskiy level (Unified..., 2000) and Apsheron regional layer.

The upper part of the section is made of Middle and Upper Pleistocene alluvial deposits bedded with erosion (layers 2-7). The age of bone-bearing layers 6 and 7 (according to the description of the section, submitted by (Zinova, 1973), these were layers 9-11 in point of observation 42) is associated with the sediments of Tobolsk level. From these layers the remains of Elasmotherium sibiricum, Mammuthus ex gr. trogontherii-chosaricus, Bison sp., were obtained which will be described below. In her studies R.A. Zinova accentuated the sporo-pollen data and the remains of the mammals were just mentioned, pointing out the general species composition from several localities, presumably, of the same age-"Equus sp., very large form with primitive attributes, associating the same with Equus steinheimensis Reich, as well as the remains of Cervus ex gr. elaphus L., Capreolus sp., Megaloceros sp., Cervidae (cf. Rangifer), Mammuthus cf. trogontherii Pohl., Palaeoloxodon cf. antiquus (Falc.)" (Zinova, 1982), with references to definitions given by E.A. Vangengeim. At the same time, on the schematic section near Krasnokutsk she marked the confinement of these remains to the sediments of Middle Pleistocene, collected at the depth of 5-7 m, but, for the most part, in the middle of the sand layer (layer 9, according to R.A. Zinova, 1982; Fig. 2). In the collections at GINRAS the remains of bison and the teeth of the elephants are stored, found by R.A. Zinova and All Union Hydrogeological Trust. The degrees of their mineralization and preservation are the same as those of the bones, obtained by us from this layer. The mollusk shells are presented by Corbicula fluminalis (Müll.). The seed flora, obtained by R.A. Zinova from the diagonal sands, is represented by Azolla interglacialica Nikit., Potamogeton vaginatus Turcz., P. filiformis Pers., Carex 
sp., Chenopodium album L., C. rubrum L., Heleocharis palustris (L.), Limnanthemum hymphoides (L.) and is associated with Tobolsk interglacial period (MIS 9-11). In sporo-pollen spectrum the arborous plants prevail (Pinus more than $70 \%$, Betula about $20 \%$ ), the herbaceous plants are represented by chenopodiacious plants, absinthium and, to a lesser degree, by Compositae.

At the border of layers 3 and 4 two teeth of "typical" Mammuthus primigenius Blum. Table 3 were found, those having lesser mineralization degree and slightly differing in color from the bones from layer 6 . Layers 3 and 4 are deposited with erosion, are irregular in spreading, which, taking into account the teeth of "typical mammoths", makes it possible to determine the time of their formation as Late Pleistocene.

\section{Materials and Methods}

The measurements of the lower jaw of steppe elephant are assumed according to Shpansky et al. (2015). The measurements of Elasmotherium sibiricum are assumed according to Khromov (1999) as supplemented by Shpansky (2013). For describing and measuring the teeth of the elephants the methodology, presented in the study by Dubrovo (1960), was used; for the dentition identifications the methodology of Sher and Garutt (1985) was applied.

The skull of Elasmotherium sibiricum was subjected to AMS radiocarbon dating analysis in the laboratory of ${ }^{14}$ CHRONO Centre for Climate, the Environment and Chronology (School of Geography, Archaeology and Paleoecology; Queen's University Belfast; Belfast, UK).

Osteological materials are represented by specimens as follows:

- Lower jaw (MN PSPI 1523/2011-HYa) of the elephant of transient type from Mammuthus ex gr. trogontherii-chosaricus with two teeth of the last dentition M3 (MN PSPI No. 1519-1/2011 and No. 1519-2/2011)

- Skull (MN PSPI 1521/2011-HYA) of Elasmotherium sibiricum Fischer 1808

- Two upper teeth of the mammoth: The last but one dentition M2 (MN PSPI No. 1520-1/2011) and the last dentition M3 (No. 1520-2/2011) of Mammuthus primigenius (Blumenbach 1799)

- Fragments of horn stem (MN PSPI 1522/2011-HYa) of Bison sp.

- To determine the general species composition of the locality and to analyze its stratigraphic position the collections GINRAS: Nos. 305, 895 were used

For the purpose of comparison the published materials on steppe elephant and Elasmotherium sibiricum were studied.

\section{Characteristics of an Object}

The obtained materials have different degree of preservation: The skull of the elasmotherium and the upper teeth of the mammoth are less mineralized and differ in color, they are gray and brown, fractured, but do not carry any traces of rolling, gnawing marks and exfoliation. The lower jaw of the steppe elephant is of red-brown color, its surface is exfoliating. The horn of the bison has some traces of being rolling and is mineralized considerably; there are developed spots of manganese oxide or of iron oxide in many places.

\section{Mammuthus ex gr. trogontherii-chosaricus}

The remains of steppe elephant are represented by the lower jaw MN PSPI instance 1523/2011-HYa with two teeth of the last dentition M3 (MN PSPI No.1519-1/2011 and No.1519-2/2011) (Fig. 3). The lower jaw is of average degree of preservation; both ascending ramification pieces are missing, the lingual alveolar walls and the mental protuberance of mandible are broken off. The jaw is not large in size (Table 1), the horizontal ramifications are thick, swollen and the ventral surfaces of the horizontal ramifications are comparatively smooth with a slight upward flexure in the middle (Fig. 3b). Symphysis is relatively high. The frontal ends of $c r$. mentalis are sharp and cylindershaped. The horizontal ramification along the frontal edge of the alveolus is considerably higher than that along the rear edge. At the buccal side of the horizontal ramification there is one mental foramen, situated in front of the fang root. The angle of divergence of horizontal ramifications is about $75^{\circ}$.

In the lower jaw the teeth of the last dentation $\mathrm{m} 3$ with average degree of erosion used to function: The front plates were worn down to the roots and the rear ones were only slightly worn, the talon has not started eroding. The tritors are slightly concaved in the crosssection plane. The plates are wide with bulges in the middle. The type of the plate attrition is as follows: $(-.-)$. The dental enamel is moderately thick with buckled riffles. The dimensions of the teeth are given in Table 2 . The same degree of preservation and the enamel thickness $(2-2.2 \mathrm{~mm})$ are characteristic of the teeth (GIRAS 305/64 and 895/44a), collected by R.A. Zinova and by the geologists of All-Union Hydrogeological Trust. One more tooth $\mathrm{m} 3$ (IZ $3515 / 64-P)$ is noted by Zhylkibayev (1975). Its morphometric data are included in general dimensional sequence of the teeth $M$. chosaricus (Zhylkibayev, 1975). The extreme values for the plates occurrence rate per $10 \mathrm{~cm}(7-8.5 \mathrm{pcs})$ and the enamel thickness $(2-2.5 \mathrm{~mm})$ are quite comparable with the parameters of the teeth of the lower jaw described in this study earlier. 


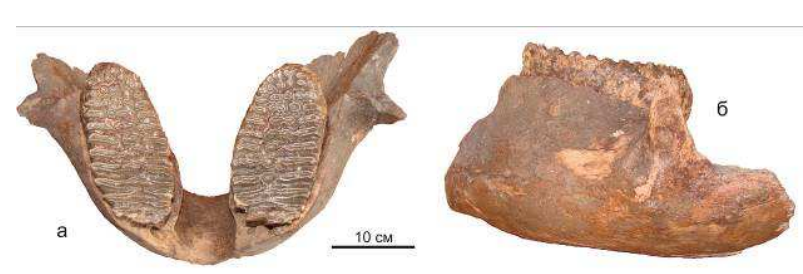

Fig. 3. Lower jaw of an elephant Mammuthus ex gr. trogontherii-chosaricus from Kozhamzhar locality MN PSPI sp. 1523/2011-HYA: A-plane view; b-side view
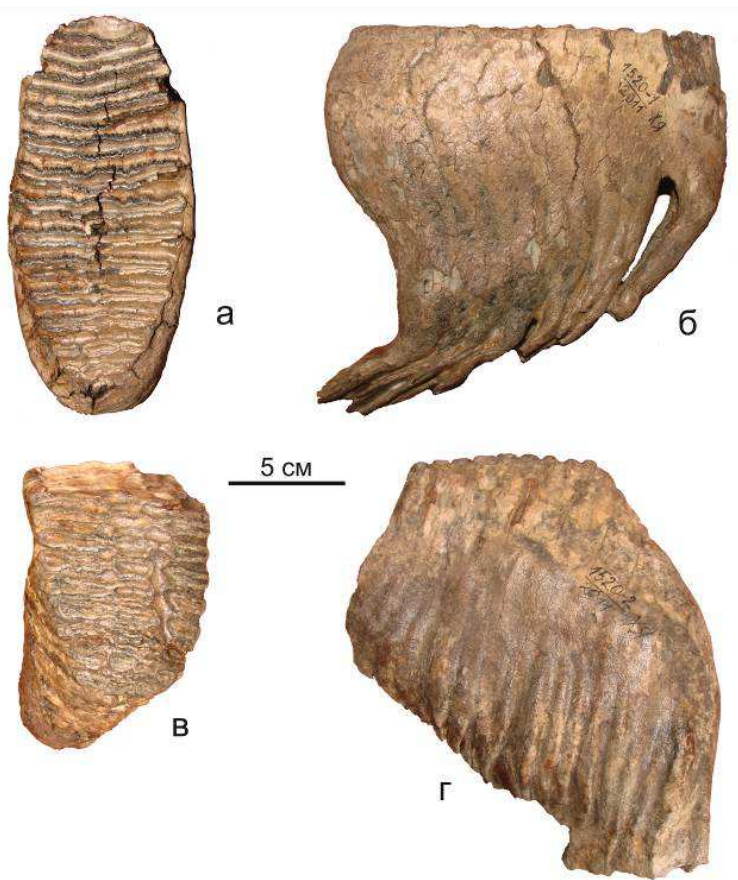

Fig. 4. Upper teeth of Mammuthus primigenius from Kozhamzhar locality: a-M2 (MN PSPI sp. 1520-1/2011) from the occlusive surface; b-side view of the same; cM3 (MN PSPI 1520-2/2011) from the occlusive surface; $d$-side view of the same

Comparison of the teeth of the Kozhamzhar elephant with those of the elephants from other localities showed that as regards the indicative characteristics (plate occurrence rate per $10 \mathrm{~cm}$ and the enamel thickness), the teeth of the Kozhamzhar elephant are more progressive than those of the typical Mammuthus trogontherii trogontherii from Western Siberia and Europe and are closer to the characteristics of M. trogontherii chosaricus Dubrovo (1966).

\section{Mammuthus Primigenius Blum}

The remains of the mammoth are represented by two upper teeth M2 and M3 MN PSPI instance 1520-1/2011 (Fig. 4) and instance 1520-2/2011 (Table 3). The dimensions and the key morphological parameters of the teeth are typical of Mammuthus primigenius from Kazakhstan localities.

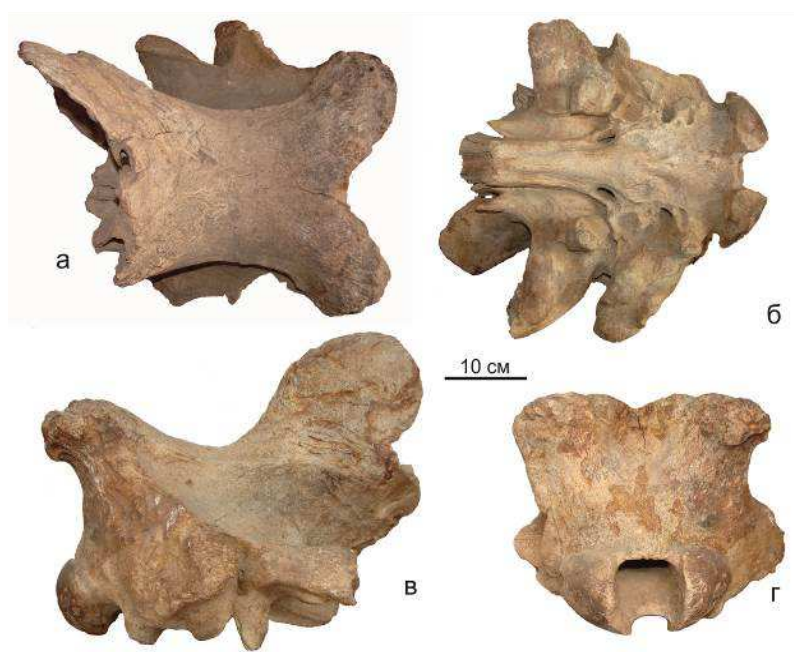

Fig. 5. Skull fragment (1521/2011 HYA) Elasmotherium sibiricum from Kozhamzhar: A-plane view; b-bottom view; c-right-side view; d-rear view

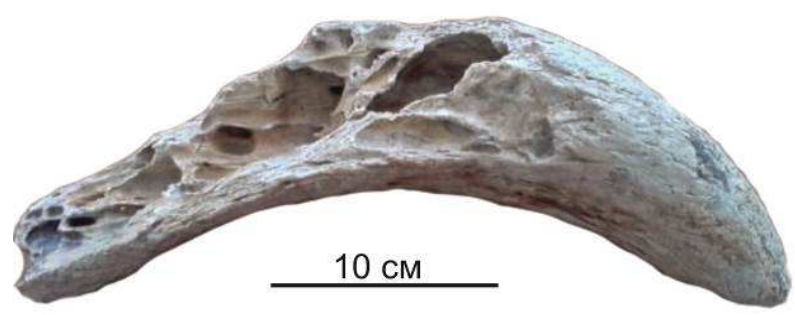

Fig. 6. Horn stem MN PSPI 1522/2011-HYA Bison sp.

\section{Elasmotherium Sibiricum Fisch}

Fragment of the skull MN PSPI inst. 1521/2011-HYa is represented by fronto-occipital part (Fig. 5), the front part of the skull was broken off at the level of the midline of the cupola-shaped eminence. Zygomatic arches are broken off at the basis; the left occipital eminence is also broken off. The post-glenoid ramifications are cone-shaped and are situated $220 \mathrm{~mm}$ away from the occipital condyles. The occipital condyles are big, oval-shaped. The cupola-shaped eminence, exposed after being broken, shows that its integral part is represented by the coarse granular bone tissue and is considerably pneumatized. The thickness of the bone in the upper part of the eminence ranges from 5 to $10 \mathrm{~mm}$ and from 10 to $15 \mathrm{~mm}$ in the lateral parts. The external surface of the cupola-shaped eminence is very rough and has multiple fissures and grooves, indicating the considerable individual age of the mammal. The occipital ridge is well developed and is of forked, dovetail shape. Angular parts of the occipital ridge are diverged at a right angle; they are massive, tuberous, overhanging extensively over the occipital condyles. The plane of the occipital bone is much flexed (concaved) in the lower part (over occipital orifice) and spreads smoothly in very hypertrophied, long and widely spaced lateral occipital prominences. The extreme points of 
occipital prominences project outside the width of zygomatic arches and represent the largest width dimension of the skull. Rear surfaces of the prominences are uneven with multiple sharp cristae and eminences. The lingual part of occipital prominences is directed laterally and to the front, in parallel to the rear part of the malar arch. Such structure makes the mammal's ear channels deep-seated. The upper part of occipital plane (between the angular parts of the occipital ridge) is occupied by a large circular-shaped indentation (with horizontal diameter of $63 \mathrm{~mm}$ ).

Table 4 gives the measurements of the skulls of Elasmotherium sibiricum from Kozhamzhar locality and from East European localities. Notwithstanding the fragmentariness of the skull, in many respects: The length of medullar compartment, the width in the occipital ridges, the width of the cupola-shaped eminence, the distance from the edge of occipital condyles to the tip of the post-glenoid appendix-this specimen is well comparable with the skulls of Elasmotherium sibiricum. At the same time, the dimensions of the Kozhamzhar specimen exceed considerably the dimensions of East European elasmotheriums.

\section{Bison sp.}

The fragment of the horn stem (MN PSPI 1522/2011$\mathrm{HYa}$ ) of bison is represented by a distal half, broken off along an oblique line. The horn belonged to a big mammal; the preserved fragment is $337 \mathrm{~mm}$ long in the chord (Fig. 6).

Table 1. The dimensions of the lower jaws of Mammuthus trogontherii

\begin{tabular}{|c|c|c|c|c|}
\hline Measurements, mm & $\begin{array}{l}\text { Kozhamzhar MN } \\
\text { PSPI } 1523 / 2011\end{array}$ & $\begin{array}{l}\text { Pyateryzhsk P2002.1149 } \\
\text { (Shpansky et al., 2008) }\end{array}$ & $\begin{array}{l}\text { Ust-Tarka IAE } 18 \\
\text { (Shpansky et al., 2015) }\end{array}$ & $\begin{array}{l}\text { Azov } 1 \text { (Baigusheva } \\
\text { and Garutt, 1987) }\end{array}$ \\
\hline Horizontal ramification length & $\mathrm{C} 425$ & 480 & 472 & \\
\hline $\begin{array}{l}\text { Horizontal ramification height } \\
\text { along the alveolus front edge }\end{array}$ & 190 & 235 & 240 & \\
\hline The same along the rear edge & 160 & 171 & 169 & 187 \\
\hline Horizontal ramification thickness (max.) & $\mathrm{C} 155$ & 180 & 194 & 174 \\
\hline $\begin{array}{l}\text { Distance between horizontal ramifications } \\
\text { along the front edge of alveolus (inside) }\end{array}$ & $60 ?$ & 70 & 85 & \\
\hline $\begin{array}{l}\text { Maximum distance between outer walls of } \\
\text { horizontal ramifications (along rear edge) }\end{array}$ & C513 & 640 & 577 & 620 \\
\hline Distance between the teeth (in front, min.) & 70 & 67 & 68 & \\
\hline Distance between the teeth in the rear (by mid-axes) & 230 & 185 & 200 & \\
\hline The same maximum at the buccal sides of the teeth & 298 & 275 & 282 & \\
\hline Symphysis height & 96 & 93 & 112 & \\
\hline $\begin{array}{l}\text { Symphysis front-rear diameter, } \\
\text { incl. mental protuberance }\end{array}$ & C101 & 160 & 150 & \\
\hline
\end{tabular}

Table 2. Dinentions (mm) of molars m3 Mammuthus trogontherii from localities in West-Siberian plain and Europe

\begin{tabular}{|c|c|c|c|c|c|c|c|c|}
\hline \multirow[b]{3}{*}{ Measurements } & & & \multicolumn{3}{|c|}{ Mammuthus trogontherii trogontherii } & \multicolumn{3}{|c|}{ Mammuthus trogontherii chosaricus } \\
\hline & \multicolumn{2}{|c|}{ Kozhamzhar MN PSPI } & \multirow{2}{*}{$\begin{array}{l}\text { Pyateryzhsk } \\
\text { MN PSPI } \\
\text { (Shpansky et al., } \\
\text { 2008) } \\
\text { m3 dex sin } \\
\text { P2002.1149 }\end{array}$} & \multirow{2}{*}{$\begin{array}{l}\text { West } \\
\text { Runton } \\
\text { (Lister and } \\
\text { Stuart, 2010) } \\
\text { m3 dex sin } \\
1992.36\end{array}$} & \multirow{2}{*}{$\begin{array}{l}\text { Azov } 1 \\
\text { (Baigusheva } \\
\text { and Garutt, 1987) } \\
\text { m3 dex sin } \\
\text { AM3 No. } \\
\text { KP-21081 }\end{array}$} & \multirow{2}{*}{$\begin{array}{l}\text { (Dubovo, } \\
\text { 1966) } \\
\text { m3 dex; sin } \\
\text { KP } 4874\end{array}$} & \multirow{2}{*}{$\begin{array}{l}\text { (Garutt, } \\
\text { 1972) } \\
\text { m3 dex; sin } \\
\text { OF-909 }\end{array}$} & \multirow{2}{*}{$\begin{array}{l}\text { Tchembaktchino } \\
\text { (Kosintsev et al., } \\
\text { 2004) } \\
\text { m3 dex sin } \\
\text { KhM-10398 }\end{array}$} \\
\hline & $\begin{array}{l}\mathrm{m} 3 \sin \\
1519-1 / 2011\end{array}$ & $\begin{array}{l}\text { m3 dex } \\
1519-2 / 2011\end{array}$ & & & & & & \\
\hline Tooth crown length & 200 & 210 & $215 ; 225$ & 430 & 418 & $258 ; 252$ & c190; c195 & 315 \\
\hline Maximum crown width & 100 & 93 & $85.5 ; 91.2$ & 104 & 91 & $98 ; 97$ & c84; c75 & 80 \\
\hline Maximum crown height & 115 & 110 & - & 167 & 168 & & & 145 \\
\hline Total amount of plates & $12+$ талон & $12+$ талон & 12,13 & 21 & 22 & 18 & $13+?$ & 22 \\
\hline $\begin{array}{l}\text { Plate occurence } \\
\text { rate at each } 10 \mathrm{~cm}\end{array}$ & $6.5-7$ & $6-6.5$ & 6 & 5.25 & 5.9 & $6 ; 5.5$ & $6.5-8$ & 5.75 \\
\hline Enamel thickness & $2.0-2.3$ & 2 & $1.8-2.5-3.1$ & $2.0-2.3-2.7$ & $2.2-2.4$ & $1.8-2.1$ & $1.8-2.1$ & 1.9 \\
\hline
\end{tabular}

Table 3. Dimensions (mm) of the upper molars of Mammuthus primigenius from some localities in Kazakhstan

\begin{tabular}{|c|c|c|c|c|c|}
\hline \multirow[b]{3}{*}{ Measurements } & \multicolumn{2}{|c|}{$\begin{array}{l}\text { Pavlodar region } \\
\text { Kozhamzhar MN PSPI }\end{array}$} & \multirow{3}{*}{$\begin{array}{l}\text { Alma-Ata, Corner of } \\
\text { Lenina/Kirova streets } \\
\text { (Zhylkibayev, 1975) } \\
\text { M3 }\end{array}$} & \multirow{2}{*}{$\begin{array}{l}\text { Ust- } \\
\text { Kamenogorsk } \\
\text { (Zhylkibayev, 1975) } \\
\text { M2 or M3 }\end{array}$} & \multirow[t]{2}{*}{$\begin{array}{l}\text { Pavlodar } \\
\text { (while meet packing } \\
\text { plant construction) } \\
\text { (Zhylkibayev, 1975) } \\
\text { M2 }\end{array}$} \\
\hline & $\mathrm{M} 2$ & M3 & & & \\
\hline & $1520-1 / 2011$ & $1520-2 / 2011$ & & w/o/No. coll. & $3490 / 53-\mathrm{P}$ \\
\hline Tooth crown length & 180 & - & 122 & 140 & 135 \\
\hline Max. crown width & 79 & 80 & 68 & 78 & 75 \\
\hline Max. crown height & 130 & 150 & 40 & 95 & 60 \\
\hline Total amount of plates & $13+$ talon & $>17$ & - & 12 & 11 \\
\hline Plate rate at each $10 \mathrm{~cm}$ & $8-9$ & 12 & 10 & 9 & 8 \\
\hline Enamel thickness & 1.8 & $1.5-2.0$ & 1.5 & $1.1-1.5$ & 1.5 \\
\hline
\end{tabular}


Table 4. Measurements of the skulls of Elasmotherium sibiricum from Kozhamzhar locality and from Eastern Europe

\begin{tabular}{|c|c|c|c|c|c|}
\hline & Measurements (mm) & $\begin{array}{l}\text { Krasnokutsk } \\
\text { (1521/2011 HYA) }\end{array}$ & $\begin{array}{l}\text { PINRAS (Titov, } \\
\text { 2008) } n=2\end{array}$ & $\begin{array}{l}\text { Sarepta } \\
\text { SLLM } 8470 \\
\text { (Khromov, 1999) }\end{array}$ & $\begin{array}{l}\text { Sarepta } \\
\text { GINRAS ASR } \\
\text { (Khromov, 1999) }\end{array}$ \\
\hline 1 & $\begin{array}{l}\text { Length of medullar compartment (from } \\
\text { lower edge of occipital orifice to orbital line) }\end{array}$ & $310(340)$ & - & & \\
\hline 2 & Width in the occipital ridges & 324 & $322.0 ; 237,0$ & 251 & 310 \\
\hline 3 & Distance between mastoid ramifications & - (inside 120) & - & & \\
\hline 4 & Width in pre-orbital apophysis & - & $457.0 ; 328.0$ & & \\
\hline 5 & Width in zygomatic arches & $-(c 415)$ & $423.0 ; 270.0$ & & \\
\hline 6 & $\begin{array}{l}\text { Minimal width of frontal bone behind } \\
\text { the cupola-shaped eminence }\end{array}$ & 188 & $142.0 ; 140.0$ & 167 & 163 \\
\hline 7 & Width of cupola-shaped eminence at the basis & 260 (c295 estimated 340) & 262 & 248 & 260 \\
\hline 8 & Height of occipital orifice & $76(68)$ & $70.0 ; 58,0$ & 57 & 63 \\
\hline 9 & Width of occipital orifice & $65(70-72)$ & $62.0 ; 58.0$ & 54 & 65 \\
\hline 10 & Length of occipital condyles (height) & 103.98 & $107.0 ; 85.0$ & 72 & 96 \\
\hline 11 & Width of occipital condyles & 240 & $182.0 ; 155.0$ & $\sim 230$ & $\sim 240$ \\
\hline 12 & $\begin{array}{l}\text { Distance from the edge of occipital } \\
\text { condyles to the tip of the postglenoid appendix }\end{array}$ & $220(260)$ & - & & \\
\hline 13 & The width of basisphenoideum & 60 & - & & \\
\hline \multirow[t]{6}{*}{14} & The width of parasphenoideum & - & - & & \\
\hline & Minimum width of occiput & 298 & & 225 & 267 \\
\hline & $\begin{array}{l}\text { Maximum width of occiput in occipital } \\
\text { prominences (exuberances) }\end{array}$ & 470 & & 376 & 447 \\
\hline & $\begin{array}{l}\text { Minimum height of occiput (from the } \\
\text { upper ridge of occipital orifice) }\end{array}$ & 200 & & 130 & 180 \\
\hline & Maximum height of occiput & $(258) / 272$ & & & \\
\hline & $\begin{array}{l}\text { Width in the external edges of the } \\
\text { articular surfaces for the lower jaws }\end{array}$ & 382 & & & \\
\hline
\end{tabular}

\section{Discussion}

Kozhamzhar locality includes relatively small amount of remains of the mammals (about 20 bones, including the materials submitted by R.A. Zinova and K.Zh. Zhylkibayev), however, their species belonging and good correlation allow undertaking a comparison of the obtained complex with already known localities in Pavlodar Priirtysh Region and evaluating the stratigraphic position of the taphocoenosis under study. The lower jaw with teeth of Mammuthus ex gr. trogontherii-chosaricus and the fragment of skull of Elasmotherium sibiricum were obtained from the sand formation (layer 6). These species have considerable stratigraphic meaning: $M$. trogontherii belongs to orthostratigraphic line of mammothoid elephants and $E$. sibiricum belongs to parastratigraphic group of rhinoceroses, being important for the south of Western Siberia, Kazakhstan and the south of Eastern Europe. The biochronological comparison of the mammothoid elephants (Archidiskodon-Mammuthus) and species Elasmotherium for the south of Eastern Europe was undertaken by Shvyreva (2015). According to her, E. sibiricus existed in Early-Middle Pleistocene and was included in Tiraspol, Singil and Khazar Faunal Complexes of Eastern Europe (Fig. 7). During this time it co-existed with $M$. trogontherii trogontherii in the end of the Early Pleistocene (Tiraspol Complex) and $M$. trogontherii chosaricus in Middle Pleistocene (Singil and Khazar Complexes).
In Central and Northern Kazakhstan and south of West Siberian Plain the remains of elasmotherium are quite numerous. Kozamkulova (1981a) notes 30 localities of Middle Pleistocene. At the territory of Pavlodar Priirtysh Region the remains of elasmotherium are known from 4 localities: Podpusk, Moiseyevka-Zhelezinka, Grigoryevka and Kozhamzhar. The finding of the vertebra and the radial bone of a very big specimen of elasmotherium near Chernoyarka village, noted by Belyayeva (1935), up to now has neither description of geological position nor of the bone materials, thus using it for an analysis is rather complicated.

Kozamkulova (1981a; 1981b) correlates the remains of elasmotherium in Kazakhstan with the Koshkurgan (= Vyatka) Faunal Complex of Middle Pleistocene, which included Equus mosbachensis, E. (Asinus) hydruntinus, Stephanorhinus kirchbergensis, Paracamelus gigas, Cervalces latifrons, Bison schoetensacki, Soergelia sp. (Kozamkulova, 1981b). The findings of elasmotherium: Lower jaws and teeth in Grigoryevka are confined as belonging to the sediments of Tobolsk Horizon of Middle Pleistocene. In this locality the remains of elasmotherium were found together with the remains of the elephant, similar to Khazar $M$. ex gr. trogontherii chosaricus. These data are in good agreement with those of (Shvyreva, 2015) for Middle Pleistocene in Eastern Europe. In Grigoryevka E. sibiricus and $M$. trogontherii chosaricus were found as a part of 
Priirtysh Faunal Complex (Shpansky et al., 2007)Bison priscus, Megaloceros giganteus ruffi, Camelus knoblochi, Saiga borealis, etc. The species composition of Grigoryevka matches very well compared with Singil Faunal Complex in Eastern Europe (Shpansky, 2009; Ilyina and Shpansky, 2014).

The situation with the remains of elasmotherium in sediments of Paleopleistocene (= Gelasian) in the section between Podpusk and Lyebyazhie (Orlov, 1930; Vislobokova, 1996) is more complicated. The most numerous findings of postcranial remains and teeth fragments were made near Lebyazhie village. Here they occur together with the remains of Homotherium sp. Eucyon minor, Archidiskodon meridionalis gromovi, Equus livenzovensis,
Paracamelus cf. gigas, Eucladoceros sp., etc., which are included in Podpusk-Lebyazhie Complex and are associated with MN 17 Mammalian Zones. The species belonging of these remains has not been identified up to now (Fig. 7). However, I.A. Vislobokova (1996) notes the similarity of the remains to those typical of E. sibiricus. Shvyreva (2004) identified E. chaprovicum with Paleopleistocene (= Gelasian) in Eastern Europe, to which a part of the found elasmotheriums have been ascribed, though earlier they had been related to E. caucasicum (Titov 2008). For Eastern Europe the time of existence of $E$. chaprovicum is correlated with the spread of Archidiskodon meridionalis gromovi. For Lebyazhie locality similar correlation is observed.

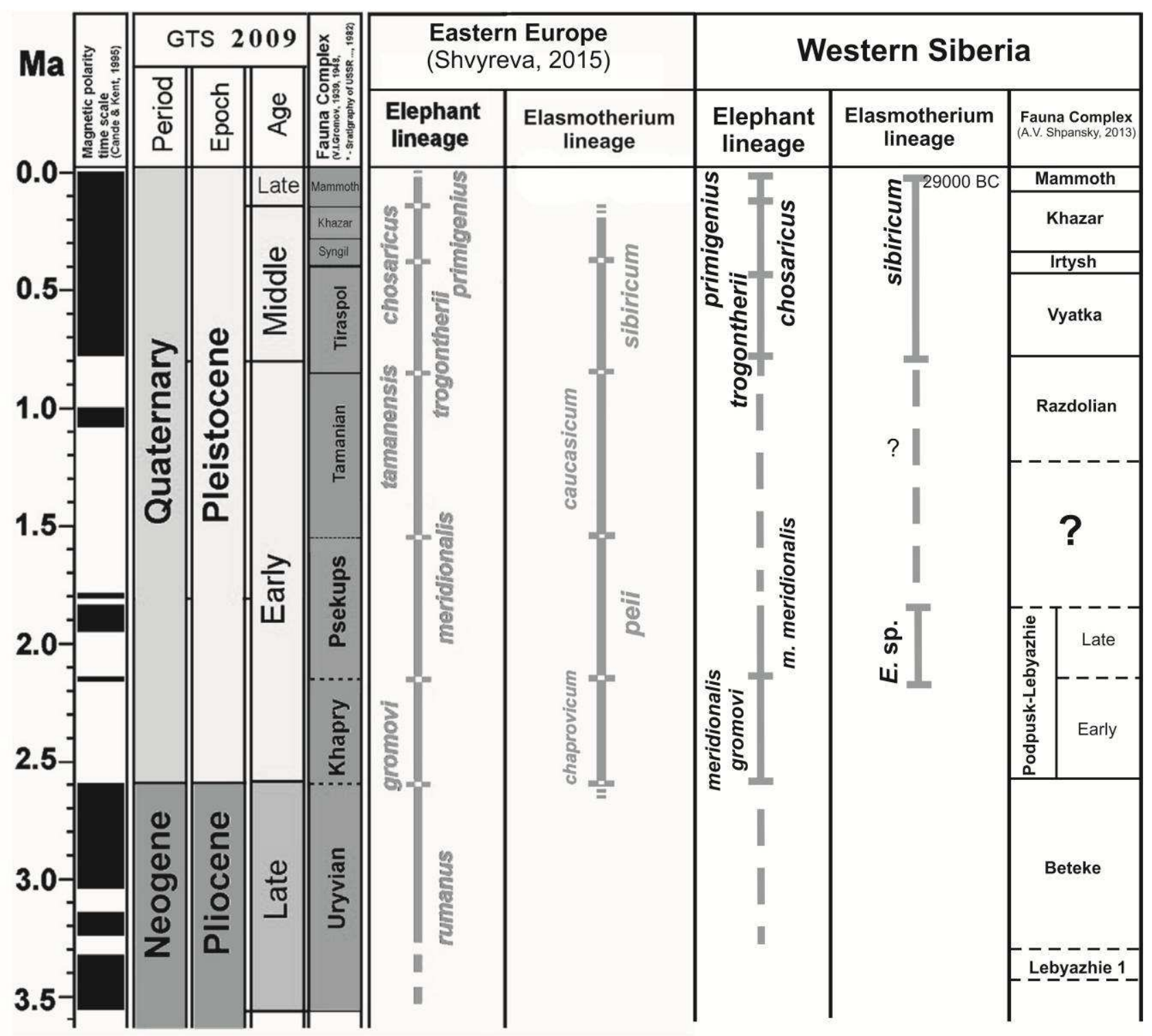

Fig. 7. Stratigraphic position of the representative of genus Elasmotherium in Eastern Europe and Western Siberia 
From the insufficiently investigated sediments, cropped out between Moiseevka and Zhelezinka, the remains of large-sized mammals of very different geological ages are known. The remains of elasmotherium are represented by the bones of the distal parts of extremities, which makes it very difficult to identify their species belonging. The bones are highly mineralized and bear some resemblance to the materials from Lebyazhie. The issue of the taxonomic ranking of the rhinoceros from Lebyazhie and Moiseevka is very important for biostratigraphy and paleozoogeography. This is made even more complicated by the fact of finding in Moiseyevka the remains of rhinoceros of species Stephanorhinus; a fragment of highly mineralized lower jaw and two teeth are stored in Pavlodar Regional Museum of Local Lore, History and Economy (according to the unpublished information).

In Kozhamzhar we identified a combination of mammalian species similar to Grigorievka locality, but with less variety of species. Our preliminary opinion was that according to biostratigraphic data both occurrences have the same geological age-Middle Pleistocene (Ilyina and Shpansky, 2014). The presence of teeth of the "typical mammoth" in the locality and small traces of rolling on the lower jaw of $M$. ex gr. trogontheriichosaricus caused our doubts. Therefore, we selected a sample from the elasmotherium skull for the radiocarbon dating analysis. The obtained date was $26038 \pm 356$ years (UBA-30522), calibration age ranges from 28985 to 27490 BC. The obtained results completely change our preliminary opinion. Now we can say that the alluvial deposits of Kozhamzhar were formed at the end of the Karginsky Thermochron of Late Pleistocene. The lower jaw of the steppe elephant found together with the elasmotherium skull was probably redeposited from more ancient deposits, though its younger age is not excluded. This requires its radiocarbon dating research. Earlier, a series of the same young radiocarbon dates was obtained by our colleagues from Ekaterinburg (Kosintsev, 2014) on the bones of elasmotheriums from localities southwest of the West Siberian Plain.

\section{Conclusion}

Survey of the found remains of Elasmotherium in Pavlodar Priirtysh Region revealed quite a long existence of these rhinos in the southeast of the West Siberian Plain. Our investigations into the Kozhamzhar occurrence showed that biostratigraphic interpretation of the geological age of the alluvial Quaternary deposits is highly complicated.

The use of radiocarbon bone dating methods allows solving some problems of biostratigraphy and specify the time of the existence and extinction of certain species of mammals. Our study following the data by Kosintsev (2014) confirmed the longer existence of Elasmotherium sibiricum within the territory of the West Siberian Plain.

The time of its extinction can now be compared with the boundary between Karginsky Thermochron and Sartan Cryochron of Late Pleistocene (boundary of MIS 3 and 2) in Western Siberia. These data significantly complicate the solution of stratigraphic and geochronological issues based on the remains of fossil mammals in the Quaternary sediments. New data are also pushing for mass radiocarbon studies of mammalian remains that were previously considered admittedly ancient and extinct more than 50-100 thousand years ago.

\section{Acknowledgement}

The authors gratefully acknowledge the Quaternary Period Stratigraphy Laboratory Superintendent of State Scientific Institute of Russian Academy of Sciences A.S. Tesakov for the granted opportunity to get familiarized with the collections gathered in Pavlodar Priirtysh area and kept in the Geological Institute. We are thankful to S.V. Svyatko, expert of ${ }^{14} \mathrm{CHRONO}$ Centre for Climate, the Environment and Chronology (School of Geography, Archaeology and Paleoecology; Queen's University Belfast; Belfast, UK) for carrying out AMS radiocarbon dating of the elasmotherium skull.

\section{Funding Information}

The research has been performed within the framework of the State task of Russian Federation № $6.657 .2014 / \mathrm{K}$. This study (research grants No 8.1.25.2015 and 8.1.80.2015) was supported by «The Tomsk State University Academic D.I. Mendeleev Fund Program» in 2015. Publication of the article is funded by the grant of the Committee of Science at the Ministry of Education and Science of the Republic of Kazakhstan 2825 GF 4 for 2015.

\section{Author's Contributions}

Andrei Valerievich Shpansky: The field research and a description of the material.

Valentina Nurmagambetovna Aliyassova: Autor designed the research plan and organized the study.

Svetlana Anatolievna Ilyina: Measurements of the samples.

\section{Ethics}

This article is original and contains unpublished material. The corresponding author confirms that all of the other authors have read and approved the manuscript and no ethical issues involved. 


\section{References}

Baigusheva, V.S. and V.E. Garutt, 1987. Skeleton of the steppe elephant Archidiskodon trogontherii (Pohlig, 1885) from the Northeastern Azov Region. Tr. Zool. Inst. Akad., 168: 21-37.

Belyayeva, Y.I., 1935. Nekotoriye danniye o chetvertichnoy faune mlekopitayushchih reki Irtysha. Tr. PIN., 4: 149-157.

Khromov, A.A., 1999. On the remains of elasmotheriidae from the funds of Saratov museum of local lore, history and economy. Paleontological J., 1: 116-122.

Dubrovo, I.A., 1966. The taxonomic position of the elephant of the Khazar Faunal Complex. Byull. Komiss. Izuch. Chetvertich. Per., 32: 63-74.

Dubrovo, I.A., 1960. Ancient elephants of the soviet union. Proc. Paleontol. Inst. Akad., 85: 79-79.

Garutt, V.E., 1972. Skeleton of a Khazar mammoth, Mammuthus cf. chosaricus Dubrovo, from the Middle Pleistocene beds of the Orya River (Kama River Basin). Ufa. Inst. Geol. Bashkir. Fil. Akad., 2: $35-55$.

Ilyina, S.A. and A.V. Shpansky, 2014. Localities of mammals of Irtysh fauna complex in Pavlodar region. Modern problems of geordaphy and geology. Proceedings of the 3rd International Scientific and Practical Conference with the Elements of a School-Seminar for Students, Aspirants and Young Scientists, (AYS' 14), Izdatelstvo TGU, Tomsk, pp: 669-673.

Kosintsev, P.A., 2014. Elasmotherium sibiricum Fisher (1808). New Data on the Period of Existence and Geographic Range. In: The Quaternary of the Urals: Global Trends and Pan-European Quaternary Records, UrFU, Ekaterinburg, pp: 67-68.

Kosintsev, P.A., N.E. Bobkovskaya, A.V. Borodin, E.V. Zinovyev and A.I. Nekrasov et al., 2004. A Steppe Elephant from the Lower Irtysh Region. Volot, Yekaterinburg.

Kozamkulova, B.S., 1969. Antropogenic fossil teriofauna of Kazakhstan. Alma-Ata, Nauka.

Kozamkulova, B.S., 1981a. Late Cenozoic hoofed mammals. Alma-Ata, Nauka.

Kozamkulova, B.S., 1981b. Elasmotherium sibiricum und sein Verbreitungsgebiet auf dem Territorium der UdSSR. Quartarpalaontologie, 4: 85-91.

Lister, A.M. and A.J. Stuart, 2010. The West Runton mammoth (Mammuthus trogontherii) and its evolutionary significance. Quaternary Int., 228: 180-209. DOI: 10.1016/j.quaint.2010.07.032

Orlov, J.A., 1930. Neue Funde fossiler Säugetiere in Sibirien. Geologic Museum, 7: 159-166.

Sher, A.V. and V.E. Garutt, 1985. On the method of determination of molar generations of extinct elephants. Proc. Zool. Inst. Akad., 131: 93-103.
Shpansky, A.V., 2013. The stratigraphic range of largesized Quaternary mammals in Western Siberia. Fundamental problems of the Quaternary, the results of the study and the main directions for further research. Proceedings of the VIII All-Russian Conference on Quaternary Research, (CQR' 13), Rostov-on-Don, pp: 707-709.

Shpansky, A.V., 2014. Skeleton of the giant deer Megaloceros giganteus giganteus (Blumenbach, 1803) (Mammalia, Artiodactyla) from the Irtysh Region near Pavlodar. Paleontological J., 48: 534-550.

Shpansky, A.V., 2009. Stratigraphic location of the Irtysh faunal complex: The results of studying and the basic approaches for further investigations. Proceedings of the 4th All-Russian Meeting on Studying the Quaternary Period, (SQP' 09), Novosibirsk, pp: 640-643.

Shpansky, A.V., V.N. Aliyasova, S.V. Titov and T.N. Smagulov, 2008. A new finding of the steppe elephant Mammuthus trogontherii Pohlig (Proboscidea, Elephantidae) in the Irtysh Region near Pavlodar, Kazakhstan. Bulletin of Mosk. O-va Ispyt. Prir., Otd. Geol., 83: 52-62.

Shpansky, A.V., G.Y. Peresvetov, V.N. Aliyasova and S.V. Titov, 2007. New findings of the quaternary mammals remains in Pavlodar Priirtysh area. Byull. Komiss. Izuch. Chetvertich. Per., 67: 97-99.

Shpansky, A.V., S.K. Vasiliev and K.O. Pecherskaya, 2015. The steppe elephant Mammuthus trogontherii (Pohlig) from the Irtysh region near Omsk. Paleontological J., 49: 304-325. DOI: $10.1134 / \mathrm{S} 0031030115030107$

Shvyreva, A.K., 2015. On the importance of the representatives of the genus Elasmotherium (Rhinocerotidae, Mammalia) in the biochronology of the Pleistocene of Eastern Europe. Quaternary Int., 379: 128-134.

DOI: $10.1016 /$ j.quaint.2015.03.052

Shvyreva, A.K., 2004. Elasmotheriidae from the Khapry Faunal Complex. Fauna Stavropolya, 12: 162-167.

Svaritchevskaya, Z.A. and M.S. Ten, 1966. History of Middle Pliocene-Quaternary deposits accumulation in Pavlodar region at Irtysh River. Nauka, Moscow.

Titov, V.V., 2008. Large Mammals of Late Pliocene in North-West Azov Region. 1st Edn., Izdatelstvo UNTs RAS, Rostov-na-Donu, pp: 262.

Unified regional stratigraphic scheme of the quaternary deposits of the west Siberian plain. 2000. Novosibirsk.

Vislobokova, I.A., 1996. The Pliocene PodpuskLebyazh'e mammalian faunas and assemblage, Western Siberia. Palaeontographia Italica, 83: 1-23.

Zhylkibayev, K.Z., 1975. Ancient elephants of Kazakhstan. Alma-Ata. 
Andrei Valerievich Shpansky et al. / American Journal of Applied Sciences 2016, 13 (2): 189.199 DOI: 10.3844/ajassp.2016.189.199

Zinova, P.A., 1973. Stratigraphy of middle to upper Pliocene and lower to middle Pliocvene deposits of central Kazakhstan. Sovetskaya Geologiya, 2: 59-70.
Zinova, R.A., 1982. Pliocene of the north of central Kazakhstan: Materials for correlating the sections of formations in Byelorussia and Kazakhstan. Nauka i tekhnika, Minsk. 